Research article urn:1sid:zoobank.org:pub:58C075B0-7409-41B7-A6F4-900A5A6BFECE

\title{
Microstomum (Platyhelminthes, Macrostomorpha, Microstomidae) from the Swedish west coast: two new species and a population description
}

\author{
Sarah ATHERTON ${ }^{1, *} \&$ Ulf JONDELIUS ${ }^{2}$ \\ ${ }^{1,2}$ Naturhistoriska riksmuseet, Box 50007, 104 05, Stockholm, Sweden. \\ "Corresponding author: Sarah.Atherton@nrm.se \\ 2Email:Ulf.Jondelius@nrm.se \\ ${ }^{1}$ urn:1sid:zoobank.org:author:1F597997-CD78-4F36-A82B-977B14DCAA6C \\ ${ }^{2}$ urn:lsid:zoobank.org:author:7F116C0B-A518-45D6-B62D-0C3B459D5F70
}

\begin{abstract}
Two new species of marine Platyhelminthes, Microstomum laurae sp. nov. and Microstomum edmondi sp. nov. (Macrostomida: Microstomidae) are described from the west coast of Sweden. Microstomum laurae sp. nov. is distinguished by the following combination of characters: rounded anterior and posterior ends; presence of approximately 20 adhesive papillae on the posterior rim; paired lateral red eyespots located level with the brain; preoral gut extending anterior to brain and very small sensory pits. Microstomum edmondi sp. nov. is a protandrous hermaphrodite with a single ovary, single testis and male copulatory organ with stylet. It is characterized by a conical pointed anterior end, a blunt posterior end with numerous adhesive papillae along the rim, and large ciliary pits. The stylet is shaped as a narrow funnel with a short, arched tip. In addition, the first records of fully mature specimens of Microstomum rubromaculatum von Graff, 1882 from Fiskebäckskil and a phylogenetic analysis of Microstomum Schmidt, 1848 based on the mitochondrial cytochrome oxidase I (COI) gene are presented.
\end{abstract}

Keywords. Macrostomorpha, Macrostomida, flatworm, meiofauna, turbellaria.

Atherton S. \& Jondelius U. 2018. Microstomum (Platyhelminthes, Macrostomorpha, Microstomidae) from the Swedish west coast: two new species and a population description. European Journal of Taxonomy 398: 1-18. https://doi.org/10.5852/ejt.2018.398

\section{Introduction}

Macrostomorpha Doe, 1986 is a group of free-living flatworms that may be found in aquatic and semiaquatic habitats all over the world (Rieger 2001). Their relatively small size, typically only 1-2 mm (although animals as large as $5 \mathrm{~mm}$ have been recorded) and paucity of distinguishing morphological characters makes taxonomic identification within the group difficult (Janssen et al. 2015).

Species identification of Macrostomorpha is largely dependent on the morphology of the reproductive system, and identification of species that predominately reproduce asexually, such as most species of Microstomum Schmidt, 1848, is particularly challenging. It is unsurprising, then, that while limited 
attention has been paid to species diversity within Macrostomorpha (e.g., Luo et al. 2011; Adami et al. 2012; Schockaert 2014; Sun et al. 2014; Janssen et al. 2015; Fang et al. 2016), current taxonomic research within the genus Microstomum is particularly scant (but see Rogozin 2015).

Species of Microstomum primarily reproduce through asexual fission, but their life cycle may also include short periods of sexual reproduction (Bauchhenss 1971; Heitkamp 1982). During that time, individual zooids will develop both male and female sexual structures, including for the male complex: single or bilateral testes, vas deferentia, a male copulatory apparatus with a seminal vesicle, stylet and antrum masculinum, and a male gonopore; and for the female complex: a single ovary, female antrum and female gonopore. Microstomum sexual maturity may be present for as little as two weeks in a year (Bauchhenss 1971; Faubel 1974) and therefore descriptions of the reproductive organs exist for only 15 of the 31 currently accepted nominal species.

Several members of Microstomum were encountered while investigating macrostomorph diversity in western Sweden. Herein, two new species of marine Microstomum are described, and a population of Microstomum rubromaculatum von Graff, 1882 from Fiskebäckskil is redescribed based upon the first records of fully sexual specimens. Additionally, we present a hypothesis regarding the phylogenetic position of the three species based on the mitochondrial cytochrome oxidase I (COI) gene and make COI barcode sequences available.

\section{Material and methods}

Sediments and aquatic vegetation were collected by hand from sites around the Sven Lovén Centre Kristineberg in Fiskebäckskil, Sweden on 17-20 Aug. 2015 and the Sven Lovén Centre Tjärnö in Strömstad, Sweden on 17-19 Jun. 2016. Exact dates and coordinates are listed in Table 1. Samples were transported back to the laboratory and marine flatworms were extracted within 48 hours following a standard $\mathrm{MgCl}_{2}$ anesthetization-decantation technique (Martens 1984). Animals were manually isolated under a Nikon SMZ 1500 stereo microscope, transferred to a glass slide and identified using a Nikon Eclipse 80i compound microscope equipped with DIC (differential interference contrast). Light micrographs and digital videos were captured with a Cannon EOS 5D Mark III digital camera. Measurements were taken with an ocular micrometer. Following documentation, individual specimens were fixed in $95 \%$ ethanol and transported to the Naturhistoriska riksmuseet in Stockholm for DNA extraction and analysis.

DNA was extracted from whole animals using the DNeasy Blood \& Tissue Kit (Qiagen, Valencia, CA) following the manufacturer's instructions. Amplification was performed via PCR using $0.2 \mathrm{ml}$ PuReTaq Ready-To-Go PCR beads (GE Healthcare). A $~ 700$ base-pair region of the COI gene was targeted using Mac_COIF+Mac_COIR (Janssen et al. 2015) or new (Mic_COIF 5'-GTT TGA GGA GGT TTG ATA GGC-3'; Mic_COIR 5'-ATC ACC CCC CTC CGT AGG AT-3') PCR and sequencing primers, and amplified with the following program: 5 minutes hotstart at $94^{\circ} \mathrm{C}$; followed by 40 cycles of 30 seconds at $94^{\circ} \mathrm{C}, 90$ seconds at $50^{\circ} \mathrm{C}$, and 60 seconds at $72^{\circ} \mathrm{C}$; and a final extension time of 10 minutes at $72^{\circ} \mathrm{C}$. Products were viewed on a $0.8 \%$ agarose gel, purified using ExoSAP-IT enzymes (Exonuclease and Shrimp Alkaline Phosphatase, GE Healthcare), and sent to Macrogen (Macrogen Europe, Netherlands) for commercial sequencing.

Thirty-five COI sequences of Microstomum and seven outgroup sequences were used in the phylogenetic analysis (Table 1). The dataset included all COI sequences of Microstomum publically available in GenBank along with new sequences of the three species presented here. Outgroups were selected based on their position in the phylogenetic hypothesis of Janssen et al. (2015).

Sequence assembly was performed in MEGA v. 6.06 (Darriba et al. 2012) and trace files were manually edited. Sequences were aligned as amino acids using the standard flatworm mitochondrial genetic code 
Table 1. List of specimens used in this study. The table lists specimens used in this study along with corresponding collection location, coordinates and date, as well as GenBank accession number, where available. * from Janssen et al. 2015; ** from Telford et al. 2000

\begin{tabular}{|c|c|c|c|c|}
\hline Species & GenBank \# & Location & Coordinates & Date \\
\hline \multirow{2}{*}{ Microstomum edmondi } & MF185700-3 & $\begin{array}{l}\text { Munkedal, } \\
\text { Sweden }\end{array}$ & $\begin{array}{l}58^{\circ} 27^{\prime} 3^{\prime \prime} \mathrm{N}, \\
11^{\circ} 41^{\prime} 10^{\prime \prime} \mathrm{E}\end{array}$ & 15 Aug. 2015 \\
\hline & MF185704-11 & $\begin{array}{l}\text { Fiskebäckskil, } \\
\text { Sweden }\end{array}$ & $\begin{array}{l}58^{\circ} 14^{\prime} 52^{\prime \prime} \mathrm{N}, \\
11^{\circ} 27^{\prime} 05^{\prime \prime} \mathrm{E}\end{array}$ & 17 Aug. 2015 \\
\hline \multirow{2}{*}{ Microstomum laurae } & MF185712 & Saltö, Sweden & $\begin{array}{l}58^{\circ} 52^{\prime} 41^{\prime \prime} \mathrm{N} \\
11^{\circ} 06^{\prime} 56^{\prime \prime} \mathrm{E}\end{array}$ & 19 Jun. 2016 \\
\hline & MF185713 & Saltö, Sweden & $\begin{array}{l}58^{\circ} 52^{\prime} 29^{\prime \prime} \mathrm{N}, \\
11^{\circ} 08^{\prime} 41^{\prime \prime} \mathrm{E}\end{array}$ & 17 Jun. 2016 \\
\hline \multirow{3}{*}{ Microstomum lineare } & AJ405979** & United Kingdom & & \\
\hline & KP730567* & $\begin{array}{c}\text { Lapptrasket, } \\
\text { Finland }\end{array}$ & $\begin{array}{l}60^{\circ} 03^{\prime} 07^{\prime \prime} \mathrm{N}, \\
23^{\circ} 40^{\prime} 19^{\prime \prime} \mathrm{E}\end{array}$ & 6 Aug. 2008 \\
\hline & MF185697-9 & Tensjön, Sweden & $\begin{array}{c}61^{\circ} 39^{\prime} 35^{\prime \prime} \mathrm{N}, \\
15^{\circ} 14^{\prime} 52^{\prime \prime} \mathrm{E}\end{array}$ & 2 Jul. 2016 \\
\hline Microstomum papillosum & KP730570* & $\begin{array}{c}\text { Koenigshafen, } \\
\text { Germany }\end{array}$ & $\begin{array}{c}55^{\circ} 02^{\prime} 24^{\prime \prime} \mathrm{N}, \\
8^{\circ} 23^{\prime} 52^{\prime \prime} \mathrm{E}\end{array}$ & 8 Mar. 2007 \\
\hline Microstomum rubromaculatum & MF185684-96 & $\begin{array}{l}\text { Fiskebäckskil, } \\
\text { Sweden }\end{array}$ & $\begin{array}{c}58^{\circ} 14^{\prime} 59^{\prime \prime} \mathrm{N} \\
11^{\circ} 26^{\prime} 45^{\prime \prime} \mathrm{E}\end{array}$ & 20 Aug. 2015 \\
\hline Microstomum sp. "B" & KP730580* & $\begin{array}{c}\text { Mangrove Bay, } \\
\text { Egypt }\end{array}$ & $\begin{array}{l}25^{\circ} 52^{\prime} 15^{\prime \prime} \mathrm{N} \\
34^{\circ} 25^{\prime} 04^{\prime \prime} \mathrm{E}\end{array}$ & 11 Jan. 2009 \\
\hline Microstomum sp. "D" & KP730576* & Pianosa, Italy & $\begin{array}{l}42^{\circ} 34^{\prime} 29^{\prime \prime} \mathrm{N}, \\
10^{\circ} 03^{\prime} 59^{\prime \prime} \mathrm{E}\end{array}$ & 30 Apr. 2010 \\
\hline \multirow[t]{2}{*}{ Myozonaria fissipara } & $\begin{array}{l}\text { KP730562*, } \\
\text { KР730575*, } \\
\text { КР730577* }\end{array}$ & $\begin{array}{l}\text { Sant Andrea } \\
\text { Bay, Italy }\end{array}$ & $\begin{array}{c}42^{\circ} 48^{\prime} 31^{\prime \prime} \mathrm{N}, \\
10^{\circ} 08^{\prime} 30^{\prime \prime} \mathrm{E}\end{array}$ & 26-30 Apr. 2010 \\
\hline & KP730574* & Pianosa, Italy & $\begin{array}{l}42^{\circ} 34^{\prime} 29^{\prime \prime} \mathrm{N}, \\
10^{\circ} 03^{\prime} 59^{\prime \prime} \mathrm{E}\end{array}$ & 30 Apr. 2010 \\
\hline \multirow{2}{*}{ Myozonaria bistylifera } & KP730573* & $\begin{array}{l}\text { Fetovaia Bay, } \\
\text { Italy }\end{array}$ & $\begin{array}{l}42^{\circ} 43^{\prime} 36^{\prime \prime} \mathrm{N}, \\
10^{\circ} 09^{\prime} 33^{\prime \prime} \mathrm{E}\end{array}$ & 26 Apr. 2010 \\
\hline & KP730584* & $\begin{array}{l}\text { Sant Andrea } \\
\text { Bay, Italy }\end{array}$ & $\begin{array}{l}42^{\circ} 48^{\prime} 31^{\prime \prime} \mathrm{N}, \\
10^{\circ} 08^{\prime} 30^{\prime \prime} \mathrm{E}\end{array}$ & 26 Apr. 2010 \\
\hline Myozonariinae & $\begin{array}{l}\text { KP730569*, } \\
\text { KP730572* }\end{array}$ & Pianosa, Italy & $\begin{array}{l}42^{\circ} 34^{\prime} 29^{\prime \prime} \mathrm{N}, \\
10^{\circ} 03^{\prime} 59^{\prime \prime} \mathrm{E}\end{array}$ & 30 Apr. 2010 \\
\hline
\end{tabular}

and then back-translated to nucleotides. The general time-reversible model with gamma distribution and proportion invariant sites was determined to be the best model of sequence evolution with three substitution schemes by jModelTest2 (Tamura et al. 2011) based upon the Akaike information criterion (Akaike 1974). Maximum Likelihood Analysis (ML) was performed in RaxmlGUI v. $1.5 b 1$ (Silvestro \& Michalak 2012) with 1000 fast bootstrap replicates.

Patristic distances were calculated using the TN93-model (Tamura \& Nei 1993) with rate variation among sites and gamma distribution. Alignment gaps and ambiguous sites were not considered. 


\title{
Results
}

\section{Taxonomy}

\author{
Order Macrostomida Karling, 1940 \\ Family Microstomidae Luther, 1907 \\ Genus Microstomum Schmidt, 1848
}

Microstomum laurae sp. nov. urn:1sid:zoobank.org:act:49378EBE-7046-49D3-BC3C-DD783580A90E

Fig. 1

\section{Diagnosis}

Strap-shaped Microstomum with body length of $760 \mu \mathrm{m}$ (two vegetative zooids) and rounded anterior and posterior ends. Posterior rim with approximately twenty adhesive papillae. Paired red eyespots $43 \mu \mathrm{m}$ long and located in the lateral margins at level of the brain. Rhabdites concentrated in the anterior end above the pharynx. Nematocysts present. Preoral gut extending anterior to brain. Reproductive system unknown. GenBank accession number for partial COI sequence MF185712-3.

\section{Etymology}

This species is dedicated to Laura R. Atherton, mother of the first author.

\section{Material examined}

\section{Holotype}

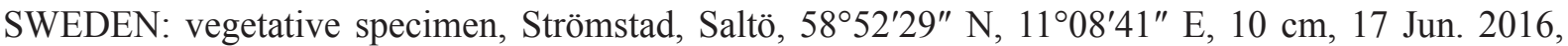
marine, eulittoral sand, S. Atherton leg. (SMNH-Type-8903, Genbank accession MF185712).

\section{Additional material}

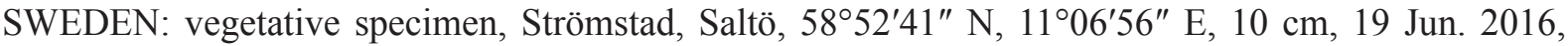
marine, eulittoral sand, S. Atherton leg. (SMNH-Type-8904, Genbank accession MF185713).

\section{Description}

Microstomum with a total body length of $760 \mu \mathrm{m}$ and two vegetative zooids. Body strap-shaped with very slight constrictions between zooids and at the level of the ciliary pits. Ratio of body width:length 1:5 in slightly compressed animal. Anterior and posterior ends rounded.

Ciliary pits very small and shallow (Fig. 1A), below eyespots, $185 \mu \mathrm{m}$ from anterior. Paired red eyespots approximately $43 \mu \mathrm{m}$ long and present in the lateral margins of the body level with brain (Fig. 1A-B).

Many small (max. diameter $10 \mu \mathrm{m}$ ) orange lipid droplets derived from food scattered across body, heavily concentrated around pharynx and anterior end (Fig. 1A-B). Body otherwise colorless or reflective of intestine.

Epidermis uniformly covered with cilia. Nematocysts present. Rhabdite bundles, 20-30 $\mu \mathrm{m}$ long, scattered about the body, particularly concentrated in the anterior end above the pharynx (Fig. 1B). Approximately twenty adhesive papillae, $8-10 \mu \mathrm{m}$ long, on the rim of the posterior end (Fig. 1C).

Mouth slit-like and $55 \mu \mathrm{m}$ long. Pharynx encompassing the second fifth of the body. Preoral gut extending well anterior to brain. Intestine evenly filled with orange droplets.

Reproductive system unknown. 


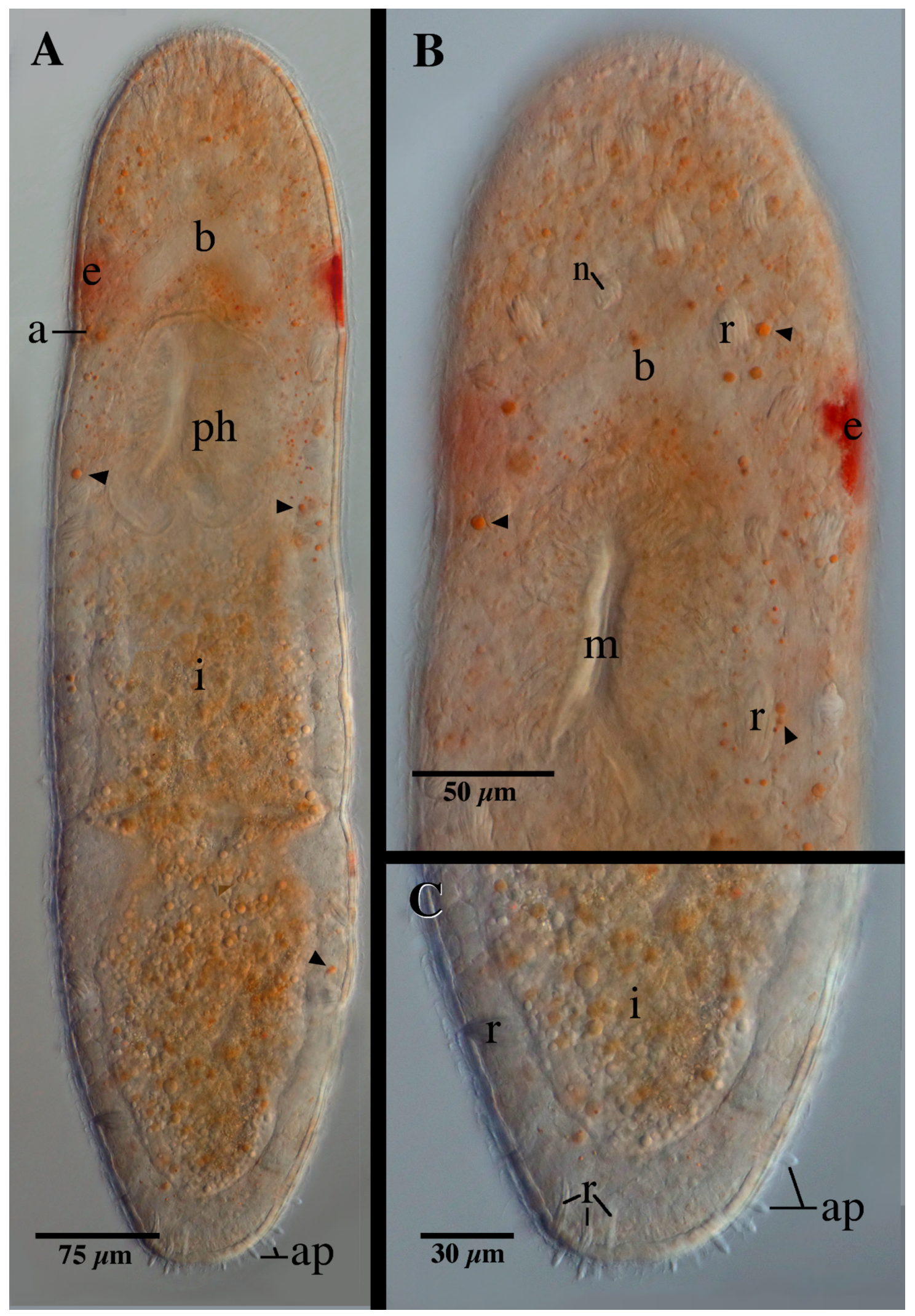

Fig. 1. Microstomum laurae sp. nov. A. Composite image of whole body. B. Anterior end. C. Posterior end. Abbreviations: $\mathrm{a}=$ auricles (ciliary pits); $\mathrm{ap}=$ adhesive papillae; $\mathrm{b}=$ brain; $\mathrm{e}=$ eyespots; $\mathrm{i}=$ intestine; $\mathrm{m}=$ mouth; $\mathrm{n}=$ nematocyst; $\mathrm{ph}=$ pharynx; $\mathrm{r}=$ rhabdite. Arrowheads indicate orange lipid droplets. 


\section{Remarks}

Eight of the currently recognized Microstomum species (M. bioculatum Faubel, 1984, M. gabriellae Marcus, 1950, M. giganteum Hallez, 1878, M. groenlandicum Levinsen, 1879, M. lineare Ørsted, 1843, M. melanophthalmum Steinbock, 1933, M. paràdii Graff, 1913 and M. spiriferum Westblad, 1953) possess pigmented eyespots. The eyespots of $M$. melanophthalmum and $M$. paràdii are black with distinct lenses, while the eyespots of M. laurae sp. nov. are red. The eyespots in M. bioculatum, M. gabriellae, M. giganteum, M. lineare and M. melanophthalmum are situated far in the front of the animal, whereas they are level with the brain in M. laurae sp. nov. Finally, the eyespot of M. groenlandicum is unpaired, red and located medially above the brain.

Microstomum laurae sp. nov. is most similar to M. spiriferum, being alike in general body size and shape as well as their small ciliary pits and large bundles of rhabdites. However, M. spiriferum can be differentiated based on the dorsal richly yellowish pigment cells and absence of adhesive papillae (Westblad 1953). M. laurae sp. nov., on the other hand, is colorless or sometimes colored by its gut contents; there are no pigment cells apart from the eyespots, and it possesses a distinct line of adhesive tubes along the posterior rim. Though both species are found on the Swedish west coast, M. spiriferum was described from sublittoral habitats between 15 and $60 \mathrm{~m}$ depth, while M. laurae sp. nov. was collected from eulittoral sand at around $10 \mathrm{~cm}$ depth.

\section{Microstomum edmondi sp. nov. urn:1sid:zoobank.org:act:E26B0ECB-C9DE-4FBB-A7D2-178A3C79F20C}

Figs $2-3$

\section{Diagnosis}

Microstomum with animal/zooid body length of $1700 / 750 \mu \mathrm{m}$. Conical pointed anterior end; blunt posterior end with numerous adhesive papillae along rim. Ciliary pits large, bottle shaped. Pigmented eyes absent. Dense field of cilia clearly covering epidermis. Preoral gut extending anteriorly to brain. Mouth distinctly encircled by glands. Protandrous hermaphrodite. Male reproductive system with single large testis. Vesicula seminalis circular to elliptical, $98 \mu \mathrm{m}$ long, and containing the ends of numerous prostate glands in the distal part. Stylet approximately $67 \mu \mathrm{m}$ long; shaped as an elongate, narrow funnel, slightly curved in one plane with a short, arched tip. Female reproductive system with single ovary and gonopore. Eggs develop caudally. GenBank accession number for partial COI sequences MF185700-11.

\section{Etymology}

This species is dedicated to Edmond T. Atherton, father of the first author.

\section{Material examined}

Holotype

SWEDEN: $\widehat{\jmath}$, Fiskebäckskil, Kristineberg Sven Lovén Center for Marine Research, 58 $14^{\prime} 52^{\prime \prime} \mathrm{N}$, $11^{\circ} 27^{\prime} 05^{\prime \prime}$ E, $25 \mathrm{~cm}, 17$ Aug. 2015, marine, eulittoral sand, S. Atherton leg. (SMNH-Type-8890, Genbank accession MF185704).

\section{Additional material}

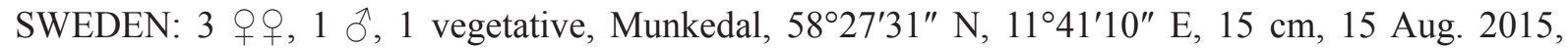
S. Atherton and Y. Jondelius leg. (SMNH-Type-8898-8902, Genbank accession MF185700-3); 2 ðరో, 5 vegetative, same data as holotype (SMNH-Type-8891-8897, Genbank accession MF185705-11). 


\section{Description}

Microstomum with vegetative chains up to four zooids long, typically two. Maximum animal/zooid length $1700 / 750 \mu \mathrm{m}$. Body strap-shaped with constrictions between zooids; ratio of body width:length approximately 1:4 in slightly compressed animal with two zooids. Anterior end conical pointed from level of ciliary pits. Posterior end blunt with row of 5-8- $\mu \mathrm{m}$-long adhesive papillae along rim (Figs $2 \mathrm{C}, 3$ )

Pigmented eyes absent. Ciliary pits large and distinct; each with a wide $43 \mu \mathrm{m}$ pore that abruptly narrows to a $15 \mu \mathrm{m}$ wide tube; total length $55 \mu \mathrm{m}$ (Figs $2 \mathrm{~A}, 3 \mathrm{~A}$ ). Epidermis noticeably covered with dense field of cilia, 10-15 $\mu \mathrm{m}$ long (Fig. 2B). Nematocysts present. Rhabdite bundles to $45 \mu \mathrm{m}$ long, occurring primarily in the posterior end of the animal (Fig. 2D).

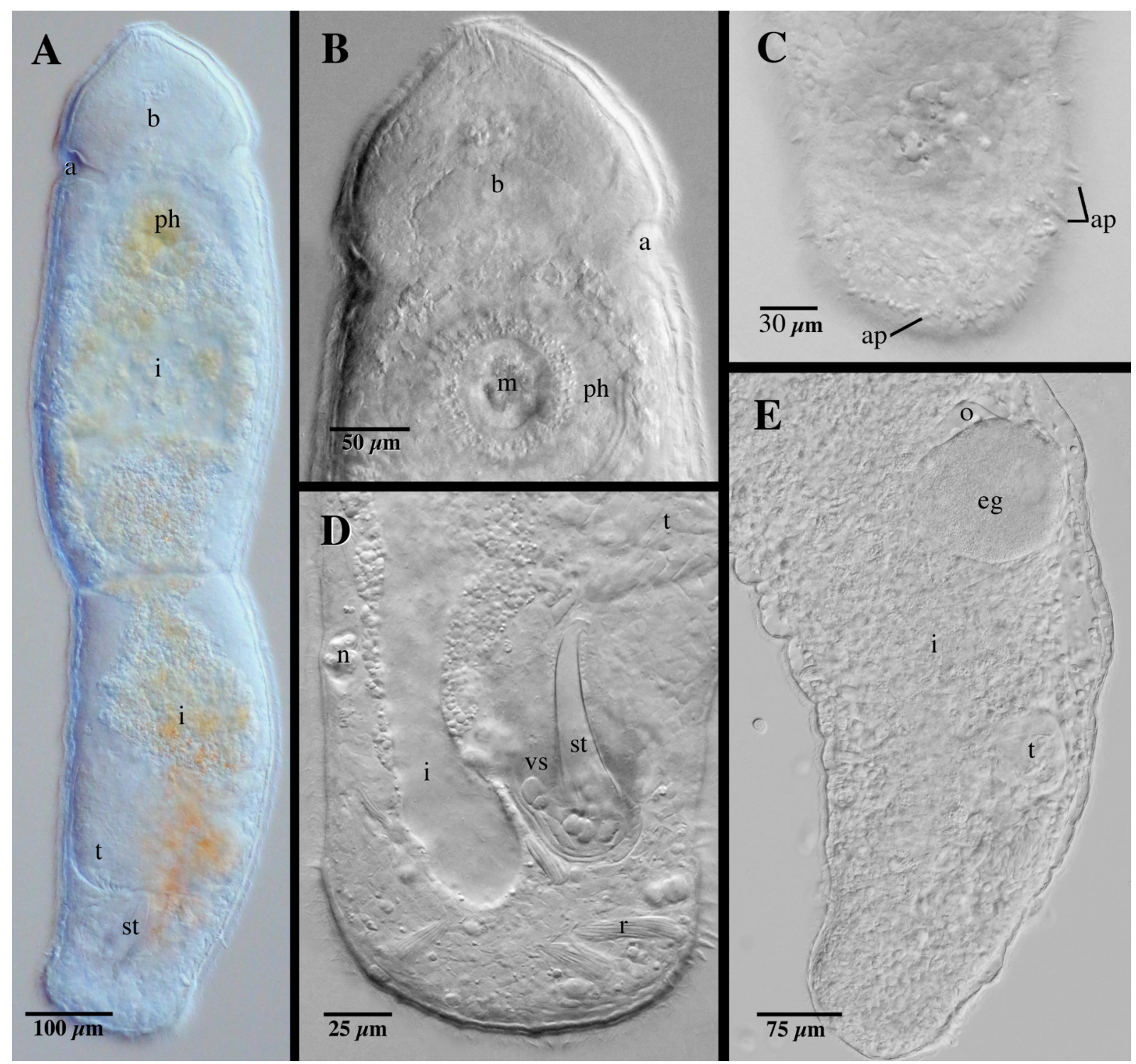

Fig. 2. Microstomum edmondi sp. nov. A. Entire body. B. Anterior end with focus on glands around mouth. C. Posterior end with focus on adhesive papillae. D. Anterior end of male specimen. E. Anterior end of female specimen. Abbreviations: $a=$ auricles (ciliary pits); $a p=$ adhesive papillae; $b=$ brain; eg = egg; $\mathrm{i}=$ intestine; $\mathrm{m}=$ mouth $\mathrm{o}=$ ovary; $\mathrm{ph}=$ pharynx; $\mathrm{r}=$ rhabdite bundle; $\mathrm{st}=$ male stylet $\mathrm{t}=$ testis; vs $=$ vesicula seminalis. 
Mouth distinctly encircled by glands (Figs 2B, 3A). Pharynx spherical, $150 \mu \mathrm{m}$ in diameter connected to yellow-brown or red-brown intestine. Body colorless. Preoral gut extending well anteriorly to brain.

Protandrous hermaphrodite. Male reproductive system with single large testis connected by short vas deferens to male copulatory apparatus (Fig. 3A). Vesicula seminalis circular to elliptical, $98 \mu \mathrm{m}$ long, and containing the ends of numerous prostate glands in the distal part (Fig. 2D). Stylet $67 \mu \mathrm{m}$ long, shaped as a tube very slightly curved in one plane and narrowing to a short, arched tip; width at base approximately $17 \mu \mathrm{m}$ and terminal opening $4 \mu \mathrm{m}$ (Figs 2D, 3C). Male pore not seen.

Female reproductive system including single mediolateral ovary and ventral female gonopore (Figs 2E, 3B). Eggs develop caudally. Very small testis posterior to ovary present in some animals (Fig. 2E).

\section{Remarks}

Almost all sexually mature specimens of Microstomum edmondi sp. nov. displayed only male or female sexual organs. Only one individual (Fig. 2E) contained both an ovary with a single egg and what appeared to be a small testis, roughly a quarter of the size of the testes of the other male specimens. This individual otherwise lacked any discernible male copulatory apparatus (vesicula seminalis or stylet). Furthermore, animals with male reproductive anatomy were generally composed of two zooids with the sexual organs in the posterior zooid only, and animals with female anatomy were always solitary. Previous life cycle studies on M. papillosum Graff, 1882 and M. spiculifer Faubel, 1974 found that male genital organs first occur in asexually produced zooids that are otherwise well-developed, and sexual development then finishes in solitary individuals (Faubel 1974, 1976; Hellwig 1987). Thus, M. edmondi sp. nov. has a protandrous hermaphroditic development. Protandrous development also occurs in other species of Microstomum, including M. bispiralis Stirewalt, 1937, M. lineare (Müller, 1773), M. papillosum and M. spiculifer (Bauchhenss 1971; Faubel 1974, 1976; Heitkamp 1982; Hellwig 1987).

In general, $M$. edmondi sp. nov. can be easily distinguished by the shape of the male stylet. Of the 15 currently accepted species of Microstomum for which sexual anatomy is known, six (M. bispiralis, M. giganteum Hallez, 1878, M. groenlandicum Levinsen, 1879, M. jenseni Riedel, 1932, M. lineare and M. spiriferum Westblad, 1953) have spiraled or coiled stylets, two (M. dermophthalmum Riedel, 1932 and M. spiculifer) have strait stylets (M. dermophthamum with a thicker distal end) and five (M. crildensis Faubel, 1984, M. ornatum Uljanin, 1870, M. papillosum, M. septentrionale Sabussow, 1900 and M. trichotum Marcus, 1950) have distinctly and continuously curved or crescent shaped stylets. Furthermore, the stylet of $M$. edmondi sp. nov. clearly differs from that of M. melanophthalmum Steinböck, 1933 by its size (67 vs $30 \mu \mathrm{m}$, respectively), as well as the lack of very wide, almost flat proximal rims and mid-way $90^{\circ}$ bend.

Of the species of Microstomum for which sexual anatomy is known, M. edmondi sp. nov. is most similar to $M$. hamatum Westblad, 1953. The male reproductive system for both includes a large seminal vesicle and a $60-70-\mu \mathrm{m}$-long stylet with similar shape. Both species additionally include individuals with only a single large testis, although animals with smaller, paired testes were also found in M. hamatum (Westblad 1953). The stylet of M. edmondi sp. nov., however, can be distinguished by the narrower base, more gradual distal tapering and a small arched tip. Microstomum hamatum has a much broader funnel-shaped stylet ending in an $180^{\circ}$ curve that forms a large hook. Other morphological differences include the pointed anterior end, large ciliary pits and lack of dark gray pigmentation in M. edmondi sp. nov. Finally, M. edmondi sp. nov. was collected from shallow, fairly clean marine sediments instead of deeper black mud.

Of the species of Microstomum for which the sexual organs remain undocumented, only eight inhabit marine waters (M. bioculatum, M. breviceps Marcus, 1951, M. davenporti von Graff, 1911, M. lucidum 


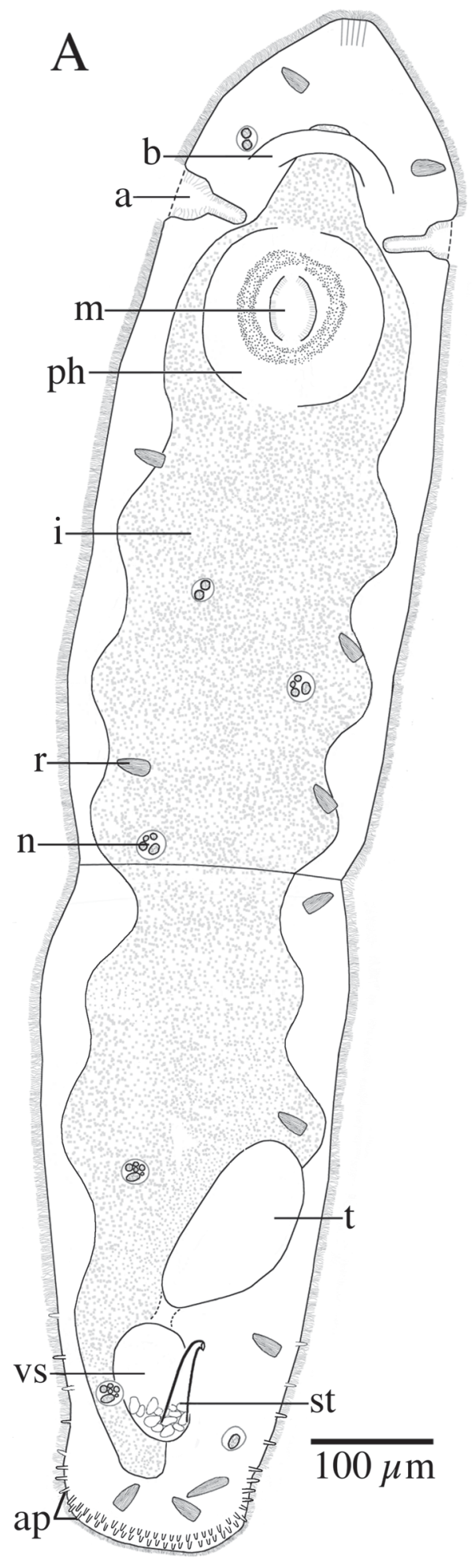

B

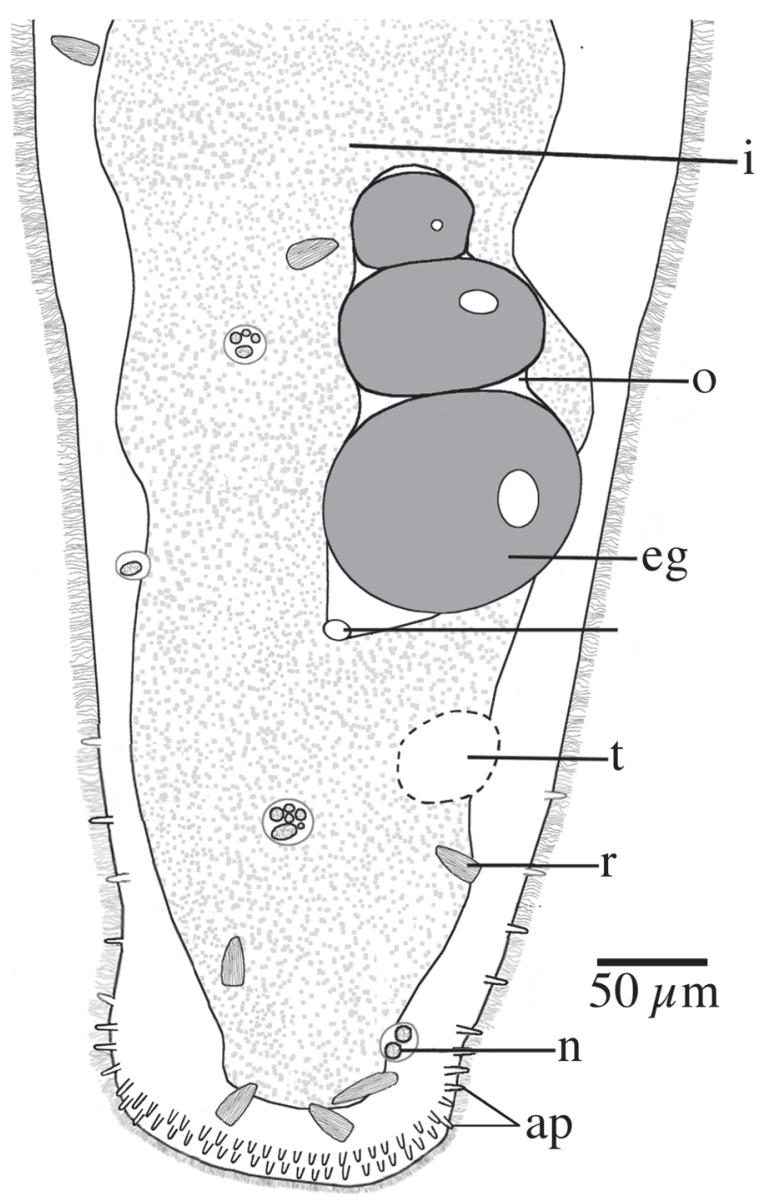

$\mathrm{C}$

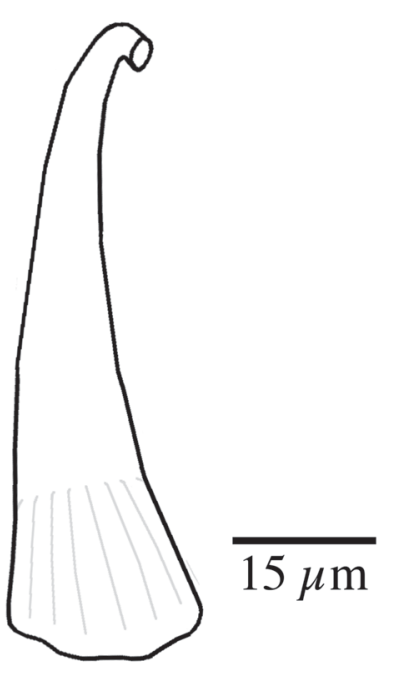

Fig. 3. Microstomum edmondi sp. nov., composite sketches. A. Entire body of male specimen. B. Posterior end of female specimen. C. Stylet. Abbreviations: $a=$ auricles (ciliary pits); $a p=$ adhesive papillae; $b=$ brain; eg = egg; $\mathrm{i}=$ intestine; $\mathrm{m}=$ mouth; $\mathrm{n}=$ nematocysts; $\mathrm{o}=$ ovary; $\mathrm{ph}=$ pharynx; $\mathrm{r}=$ rhabdites; $\mathrm{st}=$ male stylet; $\mathrm{t}=$ testis; $\mathrm{vs}=$ vesicula seminalis. 
Fuhrmann, 1896, M. mundum von Graff, 1905, M. rhabdotum Marcus, 1951, M. rubromaculatum von Graff, 1882, M. ulum Marcus, 1950). Microstomum edmondi sp. nov. is clearly most similar to M. ulum in that both have conically pointed anterior ends, large ciliary pits and large rhabdite bundles, and both lack eyespot pigmentation. Morphological differences occur in the shape of the posterior end, where a clear constriction sets apart a rounded adhesive tail plate in M. ulum while the posterior of M. edmondi sp. nov. is more paddle-like and blunt, and perhaps in the density of the locomotory cilia. Both species may be found in shallow marine sediments but are described from very distant locales, M. ulum being from the southwest Atlantic near the Island of São Sebastião, Brazil (Marcus 1950) while M. edmondi sp. nov. was described from the Swedish west coast.

Microstomum rubromaculatum von Graff, 1882

Figs $4-5$

\section{Material examined}

SWEDEN: 20 live specimens, Fiskebäckskil, Kristineberg Sven Lovén Center for Marine Research, $58^{\circ} 14^{\prime} 59^{\prime \prime} \mathrm{N}, 11^{\circ} 26^{\prime} 45^{\prime \prime} \mathrm{E}, 20$ Aug. 2015, marine, sublittoral phytal on algae, M. Curini-Galletti leg. (Genbank accession MF185684-96).

\section{Type locality}

ITALY: Gulf of Naples, Tyrrhenian Sea. Deposition not recorded.

\section{Habitat}

Marine, sublittoral phytal in algae (e.g., Sargassum sp.) or benthal on shells, fine sand and mud.

\section{Distribution}

Ireland: New Harbor, Galway, 1-2 m; Malahide Inlet, Dublin, 2 m (Southern 1936).

England: Wembury (Meixner 1938).

Faroe Islands: Vaagfjord, Suderø, 10 m (Steinböck 1931).

France: Concarneau (von Graff 1913).

Iceland: North of Ísafjörður, 1-2 m (Steinböck 1938).

Sweden: Gullmar Fjord, Fiskebäckskil, 1-2 m (Westblad 1953; pers. obs. by author).

Norway: Herdla (Westblad 1934; Karling 1953).

\section{Population description}

Microstomum with field of bright red pigmentation spots on each well-developed zooid; length of pigmentation stretches from just below the anterior tip to halfway to the brain, width of pigmentation somewhat variable: either predominately at the lateral margins and thinning toward the middle or, most frequently, a band that encircles the entire body (Fig. 4A). Other small orange-red droplets may be scattered within the parenchyma of some specimens, particularly around the anterior and pharynx (Fig. 4B-C). Body otherwise colorless, clear and reflective of intestine.

Vegetative chains to four zooids long; maximum animal/zooid body length 2000/1400 $\mu \mathrm{m}$. Body width generally consistent, accepting slight constrictions between zooids and at the level of the ciliary pits; 


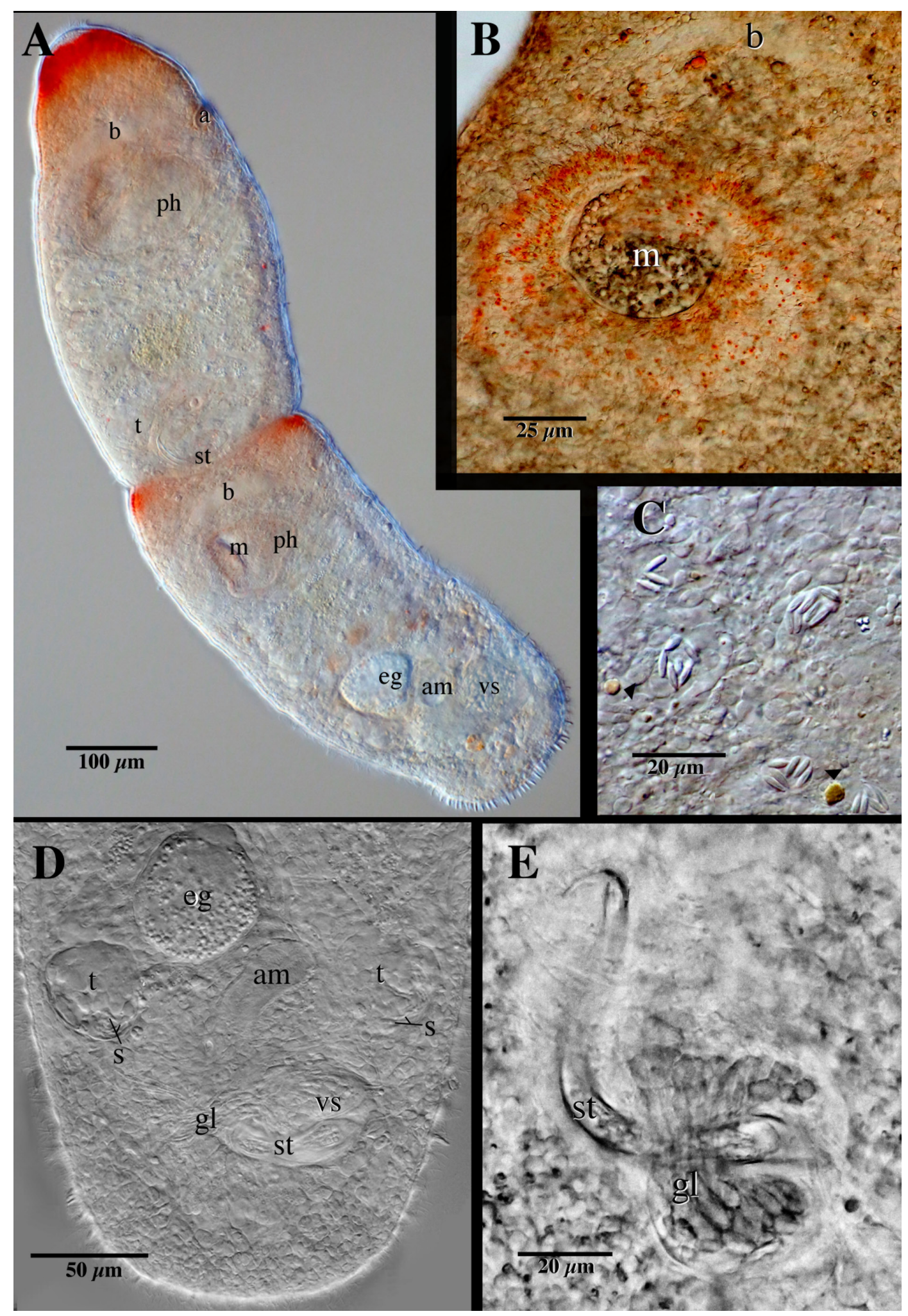

Fig. 4. Microstomum rubromaculatum von Graff, 1882. A. Entire body. B. Anterior end with focus on glands around mouth. C. Nematocysts. D. Posterior end with focus on reproductive anatomy. E. Male stylet. Abbreviations: $\mathrm{a}=$ auricles (ciliary pits); $\mathrm{am}=$ antrum masculinum; $\mathrm{b}=$ brain; $\mathrm{gl}=$ glands; $\mathrm{i}=$ intestine; $\mathrm{m}=$ mouth; $\mathrm{o}=$ ovary; $\mathrm{ph}=$ pharynx; $\mathrm{s}=$ sperm; $\mathrm{st}=$ male stylet; $\mathrm{t}=$ testis; $\mathrm{vs}=$ vesicula seminalis. Arrowheads indicate orange lipid droplets. 
slightly tapering toward the rounded anterior end. Posterior end bluntly rounded. Posterior rims of welldeveloped zooids with many 5-6- $\mu \mathrm{m}$-long posterior adhesive papillae (Fig. 5).

Epidermis uniformly covered with cilia. Bundles of 3-8 nematocysts present, scattered in the parenchyma (Karling 1966); each nematocyst 4-6 $\mu \mathrm{m}$ long (Fig. 4C). According to Westblad (1953), expelled nematocysts along the lateral body margins may resemble papillae.

Mouth slit-like at rest, but able to distend to encompass very large food. Pharynx spherical to elliptical, encompassing up to the length of the second quarter of the zooid. Preoral gut extending to brain or slightly anterior. Intestine yellow-brown or tinged with red or pink; may contain ingested prey.

Male reproductive system with paired testes located anterolaterally to male copulatory apparatus and gonopore (Figs 4D, 5). Testes round, average diameter $47 \mu \mathrm{m}$, containing little or no sperm. Vasa defferentia connect individually to circular vesicula seminalis. Numerous prostatic glands insert anteriorly in vesicula seminalis and extend ventrally around the center of stylet (Fig. 4D-E). Stylet a single, wide spiral bent around a $90^{\circ}$ angle, terminating in a $\sim 10-\mu \mathrm{m}$-long fingerlike hook (Figs $4 \mathrm{E}$, 5C-D); average length $95 \mu \mathrm{m}$ (range $75-112 \mu \mathrm{m}$ ); width largest at the base, $\sim 12 \mu \mathrm{m}$, tapering only slightly towards the distal end, $\sim 5 \mu \mathrm{m}$ at the base of the hook; opening subterminal. Stylet projects into a ciliated antrum masculinum (Fig. 4A, D).

Female reproductive system typical for the genus (Figs 4D, 5). Single ovary situated mid-body, ventral to intestine, leading to ciliated female antrum. Female gonopore separate. Eggs develop caudally.

\section{Remarks}

Collected specimens generally appeared morphologically similar to the type description (von Graff 1882) and to previous accounts of M. rubromaculatum from Fiskebäckskil. Westblad (1953) recorded M. rubromaculatum from Fiskebäckskil with vegetative chains up to four zooids long, yet all currently collected specimens except one were composed of either two weakly developed zooids separated by a faint fission plane or one or two well-developed zooids only. This follows other patterns found in species of Microstomum in which slender chains of multiple, short zooids dominate during the asexual reproductive phase of the lifecycle while larger single or double zooid animals dominate during periods of sexual reproduction (Bauchhenss 1971).

The amount of eyespot pigmentation in M. rubromaculatum can greatly vary between individuals. Specimens from Fiskebäckskil generally agreed with the original description of Graff (1882): paired, lateral eyespots composed of an accumulation of red pigmentation that extends medially to form a ring around the anterior end. However, pigmentation spots in four of the observed specimens remained clearly distinct, a phenomenon that has been recorded in other populations of M. rubromaculatum (von Graff 1913; Steinböck 1931). COI sequences were identical between specimens with two distinct eyespots and those with a circular band, which indicates amount of pigmentation is not necessarily a systematically important character. Rather, accumulation of eyespot pigmentation may be more "correlated with light intensity”, as in, e.g., Microstomum lineare (Bauchhenss 1971). Steinböck (1938) reported a single specimen of M. rubromaculatum from Iceland with a large central pigment spot that thinned toward the body margins. However, such a pattern was not observed in any of our specimens, nor otherwise recorded in any other population.

Red-orange droplets (Fig. 4B-C), that have not been previously documented in M. rubromaculatum, were observed in 18 of the 20 live specimens. The droplets ranged in size from a diameter of $\sim 2-10 \mu \mathrm{m}$ and were most often located anteriorly, especially around the pharynx. The droplets were most likely lipid deposits whose presence and coloration stems from ingested food. While such deposits have not 
been recorded before in Microstomum, colored lipid droplets are known to occur in other species of Macrostomorpha (Rieger et al. 1991).

The distribution of Microstomum rubromaculatum is wide, with populations reported from the Mediterranean, the North Sea and the Baltic. Although such patterns do occur for other macrostomorphs (e.g., Macrostomum pusillum, M. rubrocinctum, Paramalostomum dubium - see Ax 1956; Karling 1974; Armonies 1988), including other species of Microstomum (e.g., M. lineare, M. papillosum - see
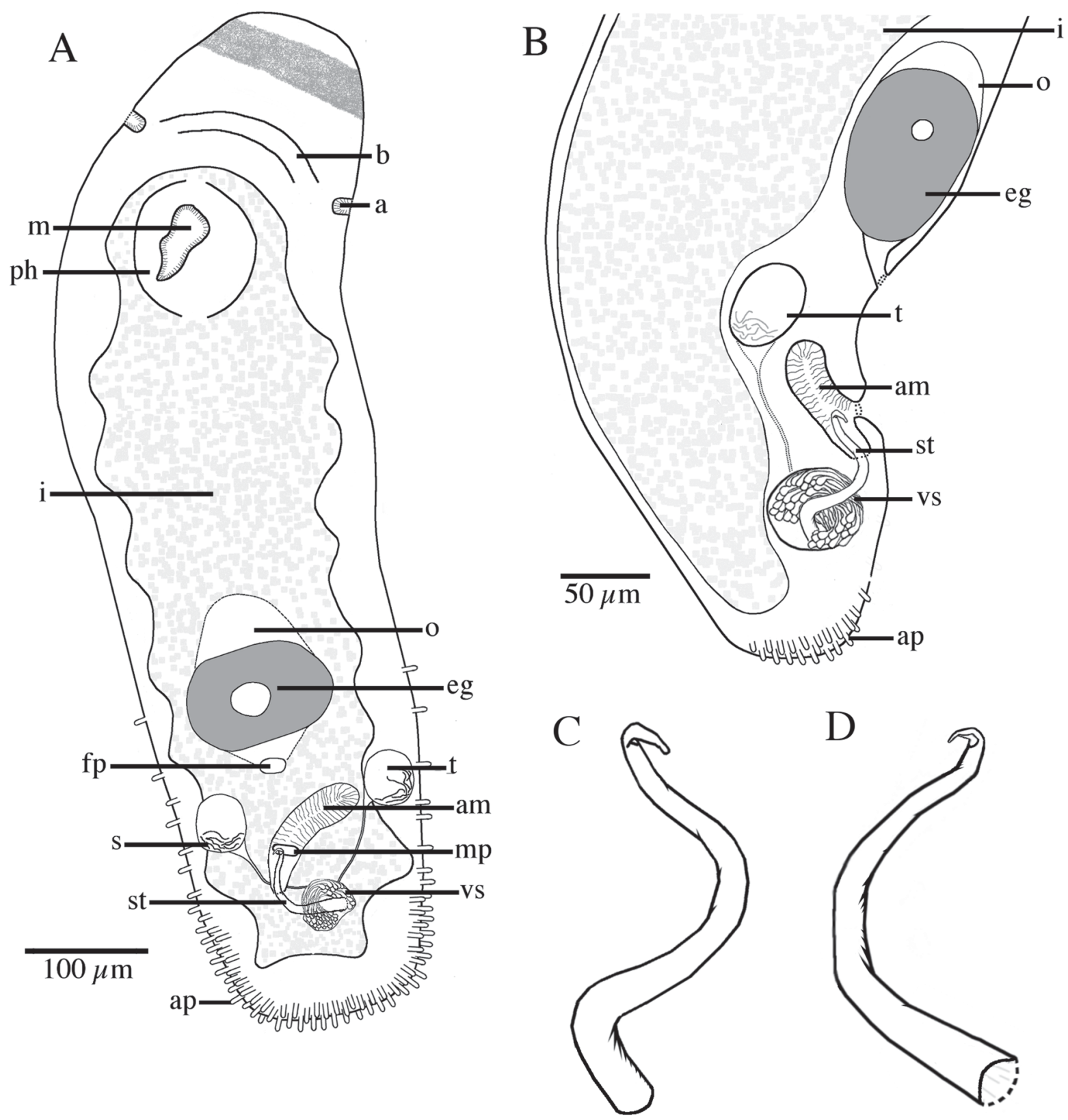

Fig. 5. Microstomum rubromaculatum von Graff, 1882, composite sketches. A. Ventral view of entire body. B. Lateral view of posterior end. C. Lateral view of stylet. D. Ventral view of stylet. Abbreviations: $\mathrm{a}=$ auricles (ciliary pits); am = antrum masculinum; $\mathrm{ap}=$ adhesive papillae; $\mathrm{b}=$ brain; $\mathrm{eg}=$ egg; $\mathrm{fp}=$ female pore; $\mathrm{i}=$ intestine; $\mathrm{m}=$ mouth $\mathrm{mp}=$ male pore; $\mathrm{o}=$ ovary; $\mathrm{ph}=$ pharynx; $\mathrm{s}=\mathrm{sperm} ; \mathrm{st}=$ male stylet; $\mathrm{t}=$ testis; $\mathrm{vs}=$ vesicula seminalis. 
Steinböck 1931; Karling 1974), the distribution may still be considered surprising giving the large geographic distances and differences in salinity and temperature (Boyer \& Levitus 1994). Evidence has increasingly shown that widespread taxa previously thought to represent a single species are in fact morphologically indistinct complexes. However, all our specimens were collected from a single location in west Sweden, and thus different populations of $M$. rubromaculatum could not be compared at this time. Sexually mature specimens of M. rubromaculatum have not been recorded from any other populations, including those inhabiting the type locality, and therefore further research may be necessary to confirm the identity of M. rubromaculatum from Fiskebäckskil, Sweden before sexual anatomy can be included in the description of the species as a whole.

\section{Phylogeny}

The maximum likelihood analysis found four moderately or highly supported clades of Microstomum (Fig. 6). M. rubromaculatum was sister to M. edmondi sp. nov. with moderate support and further formed

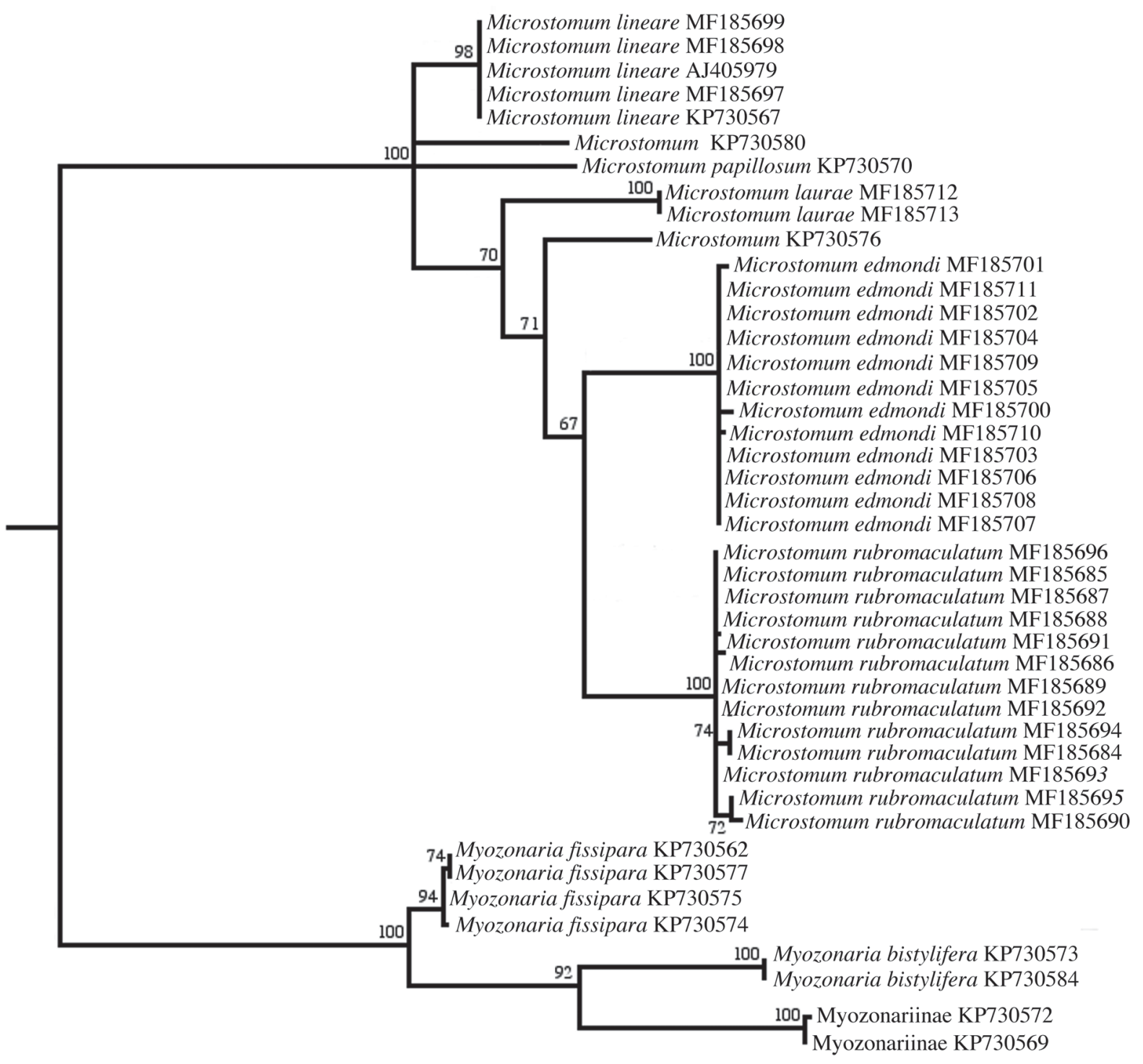

Fig. 6. Phylogenetic relationships of Microstomum Schmidt, 1848 inferred from ML analysis of partial COI gene. Outgroups were selected based on the phylogenetic hypothesis presented in Janssen et al. (2015). Numbers at nodes represent bootstrap support. Genbank accession numbers are listed after each taxon name. 
Table 2. Patristic distances between DNA sequences used in this study. Distances were calculated using the TN93-model (Tamura \& Nei 1993) with rate variation among sites and gamma distribution. Alignment gaps and ambiguous sites were not considered. Accession numbers are given after species name. Specimens with identical sequences are listed together.

\begin{tabular}{|c|c|c|c|c|c|c|c|c|c|c|c|c|c|c|c|c|c|c|}
\hline & 1 & 2 & 3 & 4 & 5 & 6 & 7 & 8 & 9 & 10 & 11 & 12 & 13 & 14 & 15 & 16 & 17 & 18 \\
\hline $\begin{array}{c}\text { 1. Myo. fissipara } \\
\text { (KP730575, 577, 562) }\end{array}$ & - & & & & & & & & & & & & & & & & & \\
\hline $\begin{array}{l}\text { 2. Myo. fissipara } \\
\text { (KP730574) }\end{array}$ & 0.003 & - & & & & & & & & & & & & & & & & \\
\hline $\begin{array}{l}\text { 3. Myozonariinae } \\
(\text { KP730569, 572) }\end{array}$ & 0.287 & 0.293 & - & & & & & & & & & & & & & & & \\
\hline $\begin{array}{l}\text { 4. Myo. bistylifera } \\
\text { (KP730584, 573) }\end{array}$ & 0.277 & 0.277 & 0.292 & - & & & & & & & & & & & & & & \\
\hline $\begin{array}{l}\text { 5. Mic. rubromaculatum } \\
\text { (MF185684-5, 87, 94) }\end{array}$ & 0.841 & 0.841 & 1.024 & 0.962 & - & & & & & & & & & & & & & \\
\hline $\begin{array}{c}\text { 6. Mic. rubromaculatum } \\
\text { (MF185686, 88, 89, 92-3, 96) }\end{array}$ & 0.817 & 0.817 & 7.011 & 0.934 & 0.006 & - & & & & & & & & & & & & \\
\hline $\begin{array}{l}\text { 7. Mic. rubromaculatum } \\
\text { (MF185690) }\end{array}$ & 0.869 & 0.869 & 1.059 & 0.978 & 0.020 & 0.014 & - & & & & & & & & & & & \\
\hline $\begin{array}{l}\text { 8. Mic. rubromaculatum } \\
\text { (MF185691) }\end{array}$ & 0.829 & 0.829 & 1.009 & 0.947 & 0.003 & 0.003 & 0.017 & - & & & & & & & & & & \\
\hline $\begin{array}{l}\text { 9. Mic. rubromaculatum } \\
\text { (MF185695) }\end{array}$ & 0.817 & 0.817 & 71.011 & 0.949 & 0.011 & 0.006 & 0.011 & 0.008 & - & & & & & & & & & \\
\hline $\begin{array}{l}\text { 10. Mic. papillosum } \\
\text { (KP730570) }\end{array}$ & 0.837 & 0.850 & 0.828 & 0.842 & 0.253 & 0.253 & 0.279 & 0.248 & 0.263 & - & & & & & & & & \\
\hline $\begin{array}{c}\text { 11. Mic. lineare } \\
\text { (KP730567, AJ405979, } \\
\text { MF185698) }\end{array}$ & 0.605 & 0.604 & 0.850 & 0.748 & 0.224 & 0.215 & 0.239 & 0.219 & 0.224 & 0.209 & - & & & & & & & \\
\hline $\begin{array}{l}\text { 12. Microstomum } \\
\text { (KP730580) }\end{array}$ & 0.699 & 0.698 & 0.849 & 0.798 & 0.244 & 0.234 & 0.254 & 0.239 & 0.244 & 0.200 & 0.178 & - & & & & & & \\
\hline $\begin{array}{l}\text { 13. Microstomum } \\
\text { (KP730576) }\end{array}$ & 0.675 & 0.675 & 0.847 & 0.771 & 0.219 & 0.209 & 0.233 & 0.214 & 0.219 & 0.233 & 0.173 & 0.224 & - & & & & & \\
\hline $\begin{array}{l}\text { 14. Mic. lineare } \\
(\mathrm{MF} 185697,99)\end{array}$ & 0.605 & 0.605 & 0.851 & 0.749 & 0.219 & 0.210 & 0.234 & 0.215 & 0.219 & 0.204 & 0.003 & 0.174 & 0.169 & - & & & & \\
\hline $\begin{array}{l}\text { 15. Mic. edmondi } \\
\text { (MF185700) }\end{array}$ & 0.843 & 0.843 & 1.079 & 0.847 & 0.224 & 0.214 & 0.238 & 0.219 & 0.224 & 0.264 & 0.225 & 0.287 & 0.165 & 0.220 & - & & & \\
\hline $\begin{array}{c}\text { 16. Mic. edmondi } \\
\text { (MF185701-2, 04-9, 11) }\end{array}$ & 0.831 & 0.831 & 1.062 & 0.835 & 0.219 & 0.209 & 0.234 & 0.214 & 0.219 & 0.258 & 0.220 & 0.282 & 0.160 & 0.215 & 0.003 & - & & \\
\hline $\begin{array}{l}\text { 17. Mic. edmondi } \\
\text { (MF185703) }\end{array}$ & 0.844 & 0.844 & 1.080 & 0.848 & 0.224 & 0.214 & 0.239 & 0.219 & 0.224 & 0.264 & 0.225 & 0.287 & 0.165 & 0.220 & 0.006 & 0.003 & - & \\
\hline $\begin{array}{l}\text { 18. Mic. edmondi } \\
\text { (MF185710) }\end{array}$ & 0.854 & 0.854 & 1.093 & 0.886 & 0.233 & 0.224 & 0.248 & 0.228 & 0.233 & 0.263 & 0.224 & 0.292 & 0.169 & 0.219 & 0.008 & 0.011 & 0.014 & - \\
\hline $\begin{array}{l}\text { 19. Mic. laurae } \\
\text { (MF185712-13) }\end{array}$ & 0.822 & 0.821 & 0.853 & 0.840 & 0.223 & 0.218 & 0.243 & 0.218 & 0.228 & 0.268 & 0.238 & 0.233 & 0.228 & 0.233 & 0.274 & 0.269 & 0.274 & 0.274 \\
\hline
\end{tabular}

a clade with an unidentified species of Microstomum (species "D" in Janssen et al. 2015; see Table 1) and $M$. laurae sp. nov. The other three species of Microstomum represented in the analysis (species "B" in Janssen et al. 2015, M. lineare, M. papillosum) individually comprised the remaining three clades. Patristic distances are presented in Table 2.

A true understanding of the evolutionary relationships within Microstomum would require multiple nuclear and mitochondrial gene sequences as well as a much greater species representation (Maddison 1997). However, the results of the ML analysis and patristic distances presented here clearly separate specimens of $M$. edmondi sp. nov., M. laurae sp. nov. and M. rubromaculatum into three distinct lineages representing the three species.

\section{Discussion}

This study extends the number of species of Microstomum known to occur within Sweden to nine. Eight species (M. hamatum, M. jenseni, M. papillosum, M. rubromaculatum, M. septentrionale, M. spiriferum, 
and now M. edmondi sp. nov. and M. laurae sp. nov.) are marine and from the Swedish west coast. The ninth species, M. lineare, occurs primarily in fresh or brackish waters with salinity up to 6-8\%o (Karling 1974) and is, perhaps, the most widespread species of Microstomum, with populations reported from waters throughout Europe, Asia and North America (Karling 1974; Kolasa et al. 1987; but see Janssen et al. 2015). Additionally, the occurrence of sexually mature specimens of M. rubromaculatum from Fiskebäckskil, Sweden brings the number of species of Microstomum with known sexual anatomy to seventeen.

\section{Acknowledgements}

We would like to acknowledge the support of the staff at the Sven Lovén Centre for Marine Research in Kristineberg and Tjärnö, Sweden. Thank you also to Dr. Marco Curini-Galletti, Dr. Lukas Schärer and Ylva Jondelius for help with sample collection and identification. This research was supported by a grant from the Swedish Taxonomy Initiative (no. DHA 2014-151 4.3) to UJ.

\section{References}

Adami M., Damborenea C. \& Ronderos J. 2012. A new limnic species of Macrostomum (Platyhelminthes: Macrostomida) from Argentina and its muscle arrangement labeled with phalloidin. Zoologischer Anzeiger 251: 197-205. https://doi.org/10.1016/j.jcz.2011.08.006

Akaike H. 1974. A new look at the statistical model identification. IEEE Transactions on Automatic Control 19: 716-723. https://doi.org/10.1109/TAC.1974.1100705

Armonies W. 1988. Common pattern of Platyhelminthes distribution in North Sea salt marshes and in the Baltic Sea. Archiv für Hydrobiologie 111: 625-636.

Ax P. 1956. Les Turbellariés des étangs côtiers du littoral méditerranéen de la France méridionale. Vie et Milieu supplément 5: 1-152.

Bauchhenss J. 1971. Die kleinturbellarien Frankens. Ein Beitrag zur Systematik und Ökologie der Turbellarien excl. Tricladida in Süddeutschland. International Revue der Gesamten Hydrobiologia 56: 609-666.

Boyer T. \& Levitus S. 1994. Quality control and processing of historical oceanographic temperature, salinity, and oxygen data. National Oceanic and Atmospheric Administration, National Environmental Satellite, Data, and Information Service 81: 1-72. US Department of Commerce, Washington DC.

Darriba D., Taboada G., Doallo R. \& Posada D. 2012. jModelTest 2: more models, new heuristics and parallel computing. Nature Methods 9: 772-772. https://doi.org/10.1038/nmeth.2109

Fang C., Wang L., Zang Y. \& Wang A. 2016. Two new species of brackish-water Macrostomum (Platyhelminthes, Macrostomida) from southern China. Zootaxa 4170 (2): 298-310. https://doi.org/10.11646/zootaxa.4170.2.4

Faubel A. 1974. Macrostomida (Turbellaria) von einem Sandstrand der Nordseeinsel Sylt. Mikrofauna Meeresboden 45: 339-370.

Faubel A. 1976. Populationsdynamik und Lebenszyklen interstitieller Acoela und Macrostomida (Turbellaria). Mikrofauna Meeresboden 56: 253-359.

Heitkamp U. 1982. Untersuchungen zur Biologie, Ökologie und Systematik limnischer Turbellarien periodischer und perennierender Kleingewässer Südniedersachsens. Archiv für Hydrobiologie supplement 64: 65-188.

Hellwig M. 1987. Ökologie freilebender Plathelminthen im Grenzraum Watt-Salzwiese lenitischer Gezeitenküsten. Microfauna Marina 3: 157-248. 
Janssen T., Vizoso D., Schulte G., Littlewood D., Waeschenbach A. \& Schärer L. 2015. The first multigene phylogeny of the Macrostomorpha sheds light on the evolution of sexual and asexual reproduction in basal Platyhelminthes. Molecular Phylogenetics and Evolution 92: 82-107.

https://doi.org/10.1016/j.ympev.2015.06.004

Karling T. 1934. Ein Beitrag zur Kenntnis der Nemertinen des finnischen Meerbusens. Memoranda Societatis pro Fauna et Flora Fennica 10: 76-90.

Karling T. 1966. On nematocysts and similar structure in turbellarians. Acta Zoologica Fennica 116: $3-28$.

Karling T. 1974. Turbellarian fauna of the Baltic proper: identification, ecology and biogeography. Fauna Fennica 27: 1-101.

Kolasa J., Strayer J. \& Bannon-O’Donnell E. 1987. Microturbellarians from interstitial waters, streams, and springs in southeastern New York. Journal of the North American Benthological Society 6: 125132. https://doi.org/10.2307/1467222

Luo H., Zhao P. \& Wang A. 2011. Research on taxonomic characters and one new recorded species of genus Macrostomum (Platyhelminthes, Macrostomida) from China. Sichuan Journal of Zoology 30: 39-44. [In Chinese.]

Maddison W. 1997. Gene trees in species trees. Systematic Biology 46: 523-536.

https://doi.org/10.1093/sysbio/46.3.523

Marcus E. 1950. Turbellaria Brasileiros. Boletins da Facultade de Filosofia Ciências e Letras Zoologia 17: 5-191.

Martens P. 1984. Comparison of three different extraction methods for Turbellaria. Marine Ecology Progress Series 14: 229-234. https://doi.org/10.3354/meps014229

Meixner J. 1938. Turbellaria (Strudelwürmer) I. Allgemeiner Teil. Die Tierwelt der Nord- und Ostsee. Akademischer Verlag, Leipzig.

Rieger R. 2001. Phylogenetic systematics of the Macrostomorpha. In: Littlewood D. \& Bray R. (eds) Interrelationships of the Platyhelminthes: 28-38. Taylor \& Francis Inc., New York.

Rieger R., Tyler S., Smith J. \& Rieger G. 1991. Platyhelminthes: Turbellaria. In: Harrison F. \& Bogish B. (eds). Microscopic Anatomy of Invertebrates. Vol. 3: Platyhelminthes and Nemertinea: 7-140. WileyLiss. Inc., New York.

Rogozin A. 2015. New species of Turbellaria in the fauna of the Urals. Biology Bulletin 42: 755-758. https://doi.org/10.1134/S1062359015080075

Schockaert E. 2014. Marine Macrostomorpha (Platyhelminthes, Rhabditophora) from the Algarve (Southern Portugal). Zootaxa 3872: 577-590. https://doi.org/10.11646/zootaxa.3872.5.8

Silvestro I. \& Michalak D. 2012. raxmlGUI: a graphical front-end for RAxML. Organism Diversity and Evolution 12: 335-337. https://doi.org/10.1007/s13127-011-0056-0

Southern R. 1936. Turbellaria of Ireland. Proceedings of the Royal Irish Academy section B 43: 43-72.

Steinböck O. 1931. Marine Turbellaria. In: Jensen S., Lundebeck W. \& Mortensen T. (eds) Zoology of the Faeroes. A.F. Høst \& Søn, Copenhagen.

Steinböck O. 1938. Marine Turbellaria. The Zoology of Iceland 2 (9): 1-26.

Sun T., Zhang L., Wang A. \& Zhang Y. 2014. Three new species of freshwater Macrostomum (Platyhelminthes, Macrostomida) from southern China. Zootaxa 4012: 120-134.

https://doi.org/10.11646/zootaxa.4012.1.6 
Tamura K. \& Nei M. 1993. Estimation of the number of nucleotide substitutions in the control region of mitochondrial DNA in humans and chimpanzees. Molecular Biology and Evolution 10: 512-526.

Tamura K., Peterson D., Peterson N., Stecher G., Nei M. \& Kumar S. 2011. MEGA5: molecular evolutionary genetics analysis using maximum likelihood, evolutionary distance, and maximum parsimony methods. Molecular Biology and Evolution 28: 2731-2739. https://doi.org/10.1093/molbev/msr121

Telford M., Herniou E., Russell R. \& Littlewood D. 2000. Changes in mitochondrial genetic codes as phylogenetic characters: two examples from the flatworms. Proceedings of the National Academy of Sciences 97: 11359-11364. https://doi.org/10.1073/pnas.97.21.11359

Von Graff L. 1882. Monographie der Turbellarien: I. Rhabdocoelida. Verlag Wilhelm Engelmann, Leipzig.

Von Graff L. 1913. Turbellaria II. Rhabdocoelida. Das Tierreich, eine Zusammenstellung und Kennzeichnung der rezenten Tierformen 35, Verlag Friedländer und Sohn, Berlin.

Westblad E. 1953. Marine Macrostomida (Turbellaria) from Scandinavia and England. Arkiv för Zoologi 4: 391-408.

Manuscript received: 3 April 2017

Manuscript accepted: 16 June 2017

Published on: 25 January 2018

Topic editor: Rudy Jocqué

Desk editor: Kristiaan Hoedemakers

Printed versions of all papers are also deposited in the libraries of the institutes that are members of the EJT consortium: Muséum national d'Histoire naturelle, Paris, France; Botanic Garden Meise, Belgium; Royal Museum for Central Africa, Tervuren, Belgium; Natural History Museum, London, United Kingdom; Royal Belgian Institute of Natural Sciences, Brussels, Belgium; Natural History Museum of Denmark, Copenhagen, Denmark; Naturalis Biodiversity Center, Leiden, the Netherlands; Museo Nacional de Ciencias Naturales-CSIC, Madrid, Spain; Real Jardín Botánico de Madrid CSIC, Spain. 